\title{
Effect of pulmonary function on right heart function in Duchenne muscular dystrophy patients
}

\author{
Sharath Subramanian ${ }^{1 *}$, Kan N Hor ${ }^{2}$, Wojciech Mazur ${ }^{3}$, Suzanne Smart ${ }^{1}$, Tam Tran$^{1}$, Nancy Halnon ${ }^{4}$, \\ Michael D Taylor ${ }^{5}$, Linda Cripe ${ }^{2}$, Subha V Raman ${ }^{1}$
}

From 18th Annual SCMR Scientific Sessions

Nice, France. 4-7 February 2015

\section{Background}

Duchenne muscular dystrophy (DMD) is an $x$-linked neuromuscular disorder in which cardiopulmonary disease leads to death in the third to fourth decade of life. Diaphragm and myocardium suffer progressive damage. While abnormalities in pulmonary and left ventricular function have been independently described, the relationship between pulmonary function and the right ventricle has not been evaluated.

\section{Methods}

Thirteen males with DMD enrolled in an ongoing clinical trial underwent CMR with multislice short axis cine imaging, using either breathhold segmented steady-state free precession or real-time acquisition techniques. Offline analysis of right ventricular volumes and ejection fractions was performed by a single reviewer blinded to PFT results using endocardial contour delineation and Simpson's rule. Forced vital capacity (FVC\%) was recorded from PFTs acquired within 10 weeks of CMR examination, and serum brain natriuretic peptide levels were measured. Subjects were classified into two groups based on having at least $80 \%$ predicted FVC.

\section{Results}

Of the 13 subjects aged $17.5 \pm 6.5$ years (mean \pm SD) who underwent CMR and concurrent FVC assessment, 11 were non-ambulatory and all subjects were on chronic oral corticosteroids at the time of imaging. Left ventricular ejection fraction (LVEF) was normal in the study group (56.9 $\pm 5.3 \%)$. The right ventricular indexed

${ }^{1}$ Cardiology, Ohio State University, Columbus, OH, USA

Full list of author information is available at the end of the article stroke volume was reduced in subjects who had less than $80 \%$ predicted FVC compared to patients who had more than $80 \%$ predicted FVC $(25.2 \pm 4.9$ vs. $32.4 \pm 5.3$ $\mathrm{mL} / \mathrm{m}^{2} ; \mathrm{p}=0.026$, Figure). There was no significant difference in the LVEF between two groups $(55.5 \pm 5.2$ vs. $58.1 \pm 5.6$, mean $\pm \mathrm{SD} ; \mathrm{p}=0.4$ ). There was no correlation between indices of right ventricular size and systolic function and BNP levels.

\section{Conclusions}

Variable RV systolic function and pulmonary function were demonstrated in boys with DMD and normal LV systolic function as assessed by CMR. Abnormal pulmonary function is correlated with reduced RV stroke volume in boys with DMD and preserved LV systolic

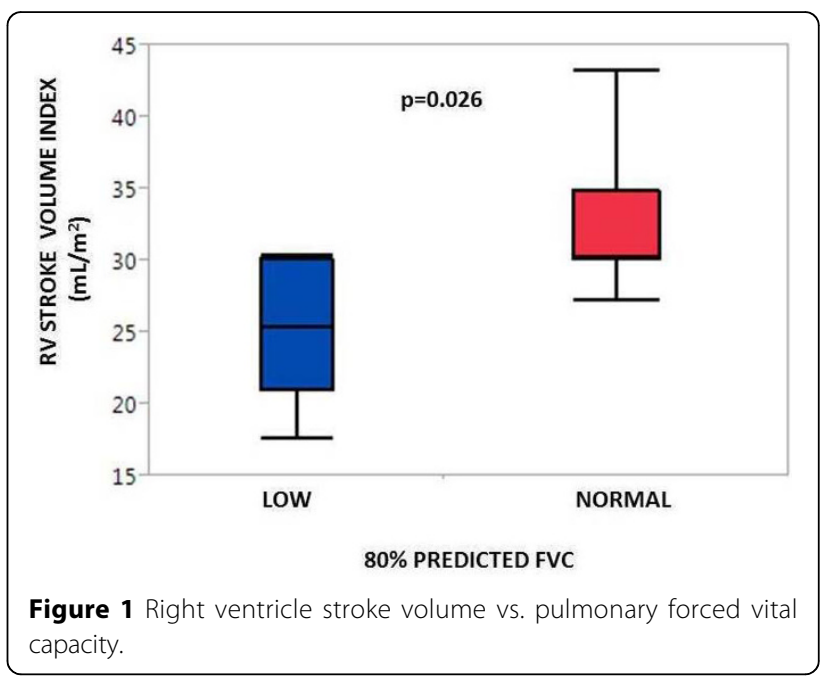


function. Further studies are needed to ascertain the prognostic significance and the influence of ventilatory support on these findings.

\section{Funding}

This work was supported by BallouSkies.

\section{Authors' details}

${ }^{1}$ Cardiology, Ohio State University, Columbus, OH, USA. ${ }^{2}$ Nationwide Children's Hospital, Columbus, OH, USA. ${ }^{3}$ The Christ Hospital Heart and Vascular Center, Cincinnati, OH, USA. ${ }^{4}$ University of California Los Angeles, Los Angeles, CA, USA. ${ }^{5}$ Cincinnati Children's Hospital Medical Center, Cincinnati, $\mathrm{OH}$, USA.

Published: 3 February 2015

doi:10.1186/1532-429X-17-S1-P279

Cite this article as: Subramanian et al: Effect of pulmonary function on right heart function in Duchenne muscular dystrophy patients. Journal of Cardiovascular Magnetic Resonance 2015 17(Suppl 1):P279.

Submit your next manuscript to BioMed Central and take full advantage of:

- Convenient online submission

- Thorough peer review

- No space constraints or color figure charges

- Immediate publication on acceptance

- Inclusion in PubMed, CAS, Scopus and Google Scholar

- Research which is freely available for redistribution

Submit your manuscript at www.biomedcentral.com/submit
C Biomed Central 